\title{
A Comparison of the Online Shopping Behavior Patterns of Consumer Groups with Different Online Shopping Experiences
}

\author{
Shwu-Ing Wu ${ }^{1} \&$ Hsin-Ti Tsai ${ }^{1}$ \\ ${ }^{1}$ Department of Business Administration, National Chin-Yi University of Technology, Taiwan, Republic of \\ China \\ Corresponding: Shwu-Ing Wu, Department of Business Administration, National Chin-Yi University of \\ Technology, No. 57, Section 2, Zhongshan Road, Taiping, Taichung, Taiwan, R.O.C. Tel: 886-4-2392-4505. \\ E-mail: wusi@ncut.edu.tw
}

Received: March 15, 2017

Accepted: April 10, 2017 Online Published: May 29, 2017

doi:10.5539/ijms.v9n3p24

URL: http://doi.org/10.5539/ijms.v9n3p24

\begin{abstract}
The appearance of Internet does not only bring changes to consumption patterns, but also to the business modes of companies, as a result of which Internet has become a perfect sales channel. When a consumer shops online, $\mathrm{s} / \mathrm{he}$ might be influenced by a huge variety of factors. In this study, $\mathrm{ABC}$ model of attitude was adopted to investigate empirically the influences of website characteristics and external stimulus on consumers' online shopping behavior. A relationship model was also established to compare the differences of consumer groups with different online shopping experiences.

Using convenience sampling, a total of 818 valid questionnaires were collected for the purpose of this study. Based on their online shopping experiences, consumers were divided into high frequency and low frequency groups in order to compare their consumption patterns as a group. According to the results, the two groups with different online shopping experiences were significantly different in three relational paths. To be specific: (1) Compared to the low frequency group, consumers in the high frequency group is more significantly positively influenced by website characteristics along the affection path during their online shopping. (2) Compared to the high frequency group, consumers in the low frequency group are more significantly positively influenced by website characteristics along the attitude path during their online shopping. (3) Compared with the low frequency group, a more significant positive influence is found among consumers in the high frequency group between consumer affection and consumer behavior path. These differences in the consumer behavior patterns of groups with different online shopping experiences according to the research results, therefore, could be used as references for online shopping business owners in their formulation of strategies.
\end{abstract}

Keywords: online shopping, website characteristics, external stimulus

\section{Introduction}

As the Internet continues to progress, network companies and e-commerce have flourished day by day. According to the Report on Internet Use and Broadband Adoption in Taiwan of Taiwan Network Information Center (2015), Internet usage in Taiwan has reached 80.3\% in 2014. Among people aged between 18 and 30, the usage is $100.0 \%$, making them the most dominant group in Internet use.

Boasting such special features as boundlessness, timelessness, great interaction, immediate response, low costs and few barriers to entry, Internet has arisen to be the perfect media of advertising, marketing and online transactions for business owners. More than that, it also means endless online marketplace potentials (Quelch \& Klein, 1996). Internet has penetrated in people's lives so completely that it has become an important channel for consumers to buy products and commodities (Prashar, Sai, \& Parsad, 2017). Internet Online Shopping, which is abbreviated as online shopping, enables consumers and business owners to combining such commercial activities as buying and selling, product and services through computer network, thus enhancing consumers' buying intention. In accordance with the latest 2014 MasterCard Online Shopping Survey, as many as $77.6 \%$ of Internet users in Taiwan use Internet for online shopping and $94.6 \%$ of all people in Taiwan have shopped online, which proportions are ranked the 3rd place among all countries and areas in Asia Pacific region (MasterCard, 2014). With the rapid growth of e-commerce industries and increase it their market values, more and more companies are so attracted that they begin to invest on the establishment of online shopping websites in order to 
provide consumers with more options. It is therefore worth conducting further investigations to see the influence factors on consumers when they choose among the great number of online shops.

As was suggested in Rangamathan \& Ganapathy (2002), an effective B2C website should have the following characteristics: security, privacy, design and information content. According moreover to the research findings (2012) of Market Intelligence \& Consulting Institute (MIC) at the Institute for Information Industry, consumers are exposed to a variety of influence factors on their purchase motivation at the time of online shopping. Apart from website characteristics, external stimuli, including price, quality, promotions, customer services, etc., also plays an essential role (Wu \& Tsai, 2016).

In order to investigate whether different "website characteristics" and "external stimuli" are influential on consumers" affection component, behavior component and cognitive component toward online shopping, this study uses the "ABC model of attitude", which was proposed in Breckler (1984), as the basis in order to confirm and probe into the influences of website characteristics and external stimuli on consumers' online shopping behavior, along with the establishment of a relationship model between them.

In addition, consumers themselves are different from each other. Some are more sensitive to prices, others more concerned with product functions, and yet others pay more attention to after-sales services. These differences could also be influential on consumers' preferences and frequency of shopping online. How online shopping experiences could influence their online shopping patterns constitutes therefore another issue worthy of in-depth investigation (Kwak, Fox, \& Zinkhan, 2002).

Given the above, with website characteristics and external stimuli as the two independent variables, this study was set out to analyze their influences on consumers' attitude toward online shopping in terms of its three components: "affection", "cognition" and "behavior". A relationship model was established for the online shopping behavior of consumers in order to further investigate the differences between groups with different online shopping experiences, with the hope to provide important references for companies in their website operations.

This study was conducted firstly by gathering relevant literature and establishing the conceptual framework, and then investigating the influences of website characteristics and external stimuli on consumers' attitude toward online shopping and their behavior patterns. Lastly, further investigations were carried out to see the differences of groups with different online shopping experiences in terms of their online shopping behavior according to the relationship model established for this purpose.

\section{Literature Review}

\subsection{Website Characteristics}

As has been pointed out in Huizingh (2000), the main characteristics of a website come in two major categories: those relating to content and those relating to design. The so-called content here refers to the information or services provided to a customer by the website, like providing the customer with an appropriate amount of information, information search engines, decision-making assistance features, etc. Design, on the other hand, refers to the way that the information content or services are provides to the customer, like such characteristics of the website as easy use, reduction in data search time, multi-media features, etc. In Hsu (2000), website characteristics were defined as: timeliness, readability and information richness. Marquis (2002), on the other hand, summarized the characteristics of a good website as: (1) download time; (2) browsability (3) product catalog; (4) website framework and (5) connectivity.

Ranganathan \& Ganapathy (2002) argued that if an online shopping website was not able to satisfy the needs of its customers, it was useless. And there were four important influence factors on the consumers in terms of the perceived quality of a $\mathrm{B} 2 \mathrm{C}$ online website, namely design, information content, security and privacy, respectively. In other words, it is necessary firstly for the website to satisfy customers' needs by providing the information or services they need, and then to present these services or information on a properly design web page, and lastly to guarantee consumers with complete security and privacy during transactions, to make sure that the customers will complete the transaction accordingly (Laia, Lia, \& Lin, 2017).

Drawing on all the above observations, website characteristics are measured from four dimensions in this study, including information content, design, security and privacy.

\subsection{External Stimulus}

According to Sawyer (1984), people's attitude, apart from being influenced by such internal factors as individual beliefs and values, will also be so changed as to be reflected on their behavior once they are exposed to external 
stimuli. Therefore, when a business owner provides the external stimuli through promotional activities, consumers will be lured to buy. External stimuli, therefore, constitute important elements in a successful marketing strategy.

In Manganari et al. (2009), a stimulus-organism-response theory was proposed to investigate consumers' behaviors and responses at online stores. In addition, it was mentioned that the external stimuli of online stores were comprised of the various virtual cues.

Kotler \& Armstrong (1997) found that external stimuli, including marketing, products, price, distribution, promotions, etc., were influential on consumers' buying decisions. Given that online stores, compared with ordinary physical stores, involve no such relevant operational costs and expenses as rent, telephones and staff, and that Internet could be used for advertising, a channel far less costly than other types of media, it is just natural that the unit price of products sold online should be lower than those sold on ordinary traditional markets (Cairncross, 1997; Martin, 1999). For an online store, as long as it has this advantage in unit price compared with ordinary physical stores (Burke, 1997), or provides customers with more information on price discounts and promotional activities using the faster network links, it will surely see an increase in the frequency of purchases on the part of consumers and number of products they buy (Covaleski, 1997). And if online stores could provide customized products, or special personalized services in response to consumers' personal needs, they will reflect themselves well among consumers (Lewis, 1997).

Given the above considerations, the dimensions of external stimuli are organized as follows in this study, including: price, quality, promotions, and customer services.

\subsection{ABC Model of Attitude}

Attitude is an acquired coherent response to a certain subject, and an individual's positive or negative assessment toward taking a certain action (Ajzen \& Fishbein, 1980). In his study, social psychologist, Breckler (1984) proposed the $\mathrm{ABC}$ model of attitudes, according to which attitude is comprised of three components: affection component (A), behavior component (B) and cognition component (C). Based on the interpretation of the model given in McLeod (2009), these three components are usually related. They are hereby described respectively as follows:

(1) Affection is an aggregation of such mental processes as emotions, moods and possible attitude, hence also a mental process in itself (Bagozzi et al., 1999). In Peter \& Olson (2001), affection is divided into emotions, special feelings, moods and evaluations. Hanna \& Wozniak (2001), on the other hand, described affection as the like or dislike towards the subject matter of attitude, and a responsive manifestation of someone's cognition of the subject matter. Consumer affection, therefore, refers to the subjective emotions incurred during the considerations for, purchase or use of a product (Cohen \& Areni, 1991).

During their online shopping, consumers are often exposed to all kinds of stimuli, as a result of which consumers' emotional state will be disturbed, thus influencing their buying decisions. Online stores, by providing such virtual information relating to emotional experiences as website atmosphere (Shen \& Khalifa, 2012), feelings invoked during the interactions with the website or browsing of the web pages (Verhagen \& Dolen, 2011), are able to guide the viewers to a certain emotional atmosphere or provoke in them a certain emotional response. And the more they could influence viewers' emotional state in a positive manner, the more they could stimulate them to buy things (Beatty \& Ferrel, 1998).

(2) Behavior is the intention or action taken by a consumer toward the subject matter of attitude, namely the possibility that $\mathrm{s} / \mathrm{he}$ will take a certain action or act in a certain way. In terms of consumer behavior, the behavior component of attitude is often reflected on their purchase intention (Ajzen, 1985).

Alba et al. (1997) suggested that customized information, if provided to the consumers at the time of online shopping, would not only satisfy the personal needs of consumers, but also boost their behavior intention. Hoffman \& Novak (1995) also found that it was possible to provide consumer-oriented marketing and communication at the time of online shopping, thus providing them with customized products or services. It could moreover provide diversified and interactive information so that consumers could have control over the process and the right to choose freely, hence their greater behavior intention (Keeler, 1995).

(3) Cognition refers to consumers' perception, beliefs and knowledge of the subject matter of attitude and comes usually from the direct experience or other relevant information sources relating to the subject matter. Cognition is defined therefore as the knowledge and perception of the subject matter of attitude as a result of combining direct experiences of it or information on it obtained from various other channels together (Peter \& Olson, 2001). 
During the process of shopping, consumers' purchase intention will be affected by their cognition, and the values perceived by the consumers in this process will in return affection their satisfaction (Park, 2007). As was suggested in Bei \& Chiao (2001), the more a consumer is satisfied with the values perceived, the higher chances that there will be a transaction.

On the contrary, the cognitive risks perceived by consumers during online shopping are often greater than when they are shopping at traditional physical stores (Van Den Poel \& Leunis, 1999). In Liebermann \& Stashevsky (2002), it was stressed that cognitive risks could be significantly influential on consumers' buying decisions, and particularly so in the context of virtual transactions. To be specific, the existence of cognitive risks will influence consumers' purchase intention negatively.

McCorkle (1990) also suggested that non-store retailing, as compared to traditional physical stores, meant higher cognitive risks for consumers. Despite of the marketing channels provided by the Internet, the rich information content and convenience without limits of time or space, non-store retailing is limited in providing consumers with personal experience and opportunity to try the product, hence the higher cognitive risks.

\subsection{Online Shopping Experience}

Consumer characteristics, apart from common demographic variables, include usually also a consumer's Internet use habit and past shopping experiences (Childers, 1986). Alba et al. (1997) suggested that it was advisable for Internet business owners to provide customized information according to their different needs, by which not only they could not only satisfy the individual needs of customers, but also remove the need to worry about the professional qualities of their staff, like business owners relying on traditional sales channels did.

In Modahl (2000), the concept of "technographics" was proposed, by which consumers would be divided according to their financial conditions on the Internet. These consumers would then be further categorized into different online shopping groups based on their motivation to use technology and their financial capacities for technological products. Being a form of non-store retailing, online shopping means that it is impossible for its consumers to actually touch the products to check their quality, hence the higher risks perceived for online shopping. Therefore, as the purchase frequency increases, consumers will build more experiences, which will influence their buying decisions in the future (Mallapragada, Chandukala, \& Qing, 2016). This is why differences in online shopping experiences are used in this study to investigate their influences on the relationship model proposed here.

\section{Research Hypotheses}

\subsection{Relationship between Website Characteristics and Components of Consumers'Attitude}

As the Internet becomes more and more popular, everyone learns to use it and online shopping has emerged as a new form of shopping. It constitutes therefore an interesting question as to how these online shopping websites should be like in order to attract consumers' attention, or make them buy things. In their study on the online bookstores in Taiwan, Liang \& Lai (2002), it was suggested that the design of websites were just as important as the price of products. For a poorly designed website, even if the products sold on it are cheap, consumers will still not be drawn to buy things. Actually, the design of website was even more important than the reputation of it. Similarly, it was argued in Angelide (1997) that although online stores might have far more advantages as compared to traditional stores, success of these stores relied however on the design of their web pages. When a consumer shops online, apart from the products themselves, they are also exposed to the websites, which could not only play the role of exhibiting products and providing information, but also part of the services. Therefore, during their online shopping, the better a consumer feels about a website, or the more satisfied they feel about using the website, the more positive their attitude and actions will be (Janda, Trocchia, \& Gwinner, 2002).

In the study on B2C websites of Rangamathan \& Ganapathy (2002) conducted to investigate the key characteristics of these websites, it was found that $\mathrm{B} 2 \mathrm{C}$ websites were featured by four major characteristics: information content, design, security and privacy. Among them, security is considered the most important and in order of importance, the other three are ranked as: privacy, design and information content. All of them are found to be influential on consumers' attitude toward online shopping. For example: it was suggested in Richmond (1996) that if a website was designed to have some entertainment features, Internet users would browse it longer in a favorable mood and even have the intention to purchase; according to Daniel (2000), the first step that should be taken to attract consumers was to lure them onto the website via visual presentations; Dayal et al. (1999), Lee \& Turban (2002) argued that since consumers' trust was related to personal traits, culture and experience, the more they believed in the security of a website, the more they would prefer to buy on this website; Salisbury et al. (2001) also suggested that consumers' security awareness was decisively influential on 
their attitude and behavior intention. Given the above, it is known that all the four major website characteristics: information content, design, security and privacy, are influential on Internet users' attitude, driving them to form emotion and cognition toward online products and invoking their purchase intention, thus ultimately making them buy things.

Based on the above observations, the following hypotheses are deduced:

H1: At the time of online shopping, "website characteristics" are significantly positively influential on consumers' affection toward online shopping.

H2: At the time of online shopping, "website characteristics" are significantly positively influential on consumers' behavior toward online shopping.

H3: At the time of online shopping, "website characteristics" are significantly positively influential on consumers' cognition of online shopping.

\subsection{Relationship between External Stimuli and Components of Consumers'Attitude}

External stimuli are important influence factors on consumers' buying behavior. According to Kotler \& Armstrong (1998), external stimuli were influential on consumers' buying decisions. External stimuli include: marketing strategies provided by the manufacturers, situational factors at the time of purchase; influence factors controllable to the market staff like advertising or promotional activities (Piron, 1991; Puri, 1996; Dholakia, 2000); and lastly appeal of certain products (Shiv \& Fedorikhin, 1999; Dholakia, 2000). Whether external stimuli are influential on consumers' attitude toward online shopping, on the other hand, is the question that this study intends to probe into using the $\mathrm{ABC}$ model of attitude. With external stimuli as the independent variables, therefore, this study is set out to investigate their influences on consumers' attitude. The following hypotheses are propose:

H4: At the time of online shopping, "external stimuli" are significantly positively influential on consumers' affection toward online shopping.

H5: At the time of online shopping, "external stimuli" are significantly positively influential on consumers' behavior toward online shopping.

H6: At the time of online shopping, "external stimuli" are significantly positively influential on consumers' cognition of online shopping.

\subsection{Relationship between the Three Components of the Attitude toward Online Shopping}

According to the tricomponent attitude model proposed in Lutz (1991), attitude is comprised of cognition, affection and behavior. Lin (2002) also suggested that in terms of attitude, consumers would usually follow a principle of consistency, namely maintaining coherence and harmony on attitude, affection and cognition, the three components of attitude. In order to maintain the balance between the three, it is just natural that they should be mutually influential. It is moreover mentioned in Solomon (2011) that in the formation of attitude, the three components would appear in a fixed order, which is decided by a variety of factors like consumers' buying behavior or degree of participation. These factors, eventually, will also result in the changes in the above-said order.

In this study, Experimental Hierarchy, which was proposed in Solomon (2002) was adopted together with the $\mathrm{ABC}$ model of attitudes to confirm attitude models toward online shopping. According to Experimental Hierarchy, it is with strong emotion to a brand that users will want to buy things, and then become aware of and ultimately supportive of their behavior. For example: After the salespersons bring a pleasant message to the consumers through advertisements, a positive feeling toward the product will occur among the consumers, who will then be driven to buy the product and develop some awareness toward the product. This is a process of feeling, executing and thinking (Solomon, 2002). According to Experimental Hierarchy, therefore, consumers will firstly have some feelings toward the product or brand the hierarchy represents, buy things according and ultimately develop some awareness or cognition toward the product after using it (Tseng, 2013).

Based on these observations given by the scholars, being unable to see the physical products at the time of online shopping, consumers will firstly develop emotion toward the product as they are described on the website. As the emotion develops further, they will be driven to buy things. After using the product, they will truly know whether the product is good or not (Wirtz \& Bateson, 1999; Wirtz et al., 2000). Accordingly, the following hypotheses are proposed in this study:

H7: The "affection" that consumers have toward online shopping is significantly positively influential on their "behavior" at the time of online shopping. 
H8: Consumers' "behavior" at the time of online shopping is significantly positively influential on their "cognition" toward online shopping.

\subsection{Influences of Online Shopping Experiences on Consumers' Online Shopping Behavior Pattern}

As it is impossible for consumers unfamiliar with the Internet to shop online, the longer a consumer has used the Internet, the more it indicates that she is interested in the Internet, needs it or is emotionally attached to it, namely the higher the degree that she is involved in it, hence the greater possibilities for them to become online shopping consumers (Barki \& Hartwick, 1989; Childers, 1986). Those who use the Internet more frequently, conveniently and experienced in online shopping might have higher intention to shop online. That is to say, the familiarity with and acceptance of the Internet on the part of consumers could also be important influence factors on their intention to shop online (Modahl, 2000). In order to investigate the differences in the online shopping behavior patterns of groups with different online shopping experiences, the following hypothesis is proposed in this study:

H9: Groups with different online shopping experiences are significantly different in terms of the path and tie strength of their online shopping behavior pattern.

\section{Research Design}

\subsection{Research Framework}

Given the above literature review, the research hypotheses and research structure of this study are established. Questionnaire design, sample survey and analyses are then conducted to confirm the research hypotheses proposed in this study. Figure 1 shows the Research Structure.

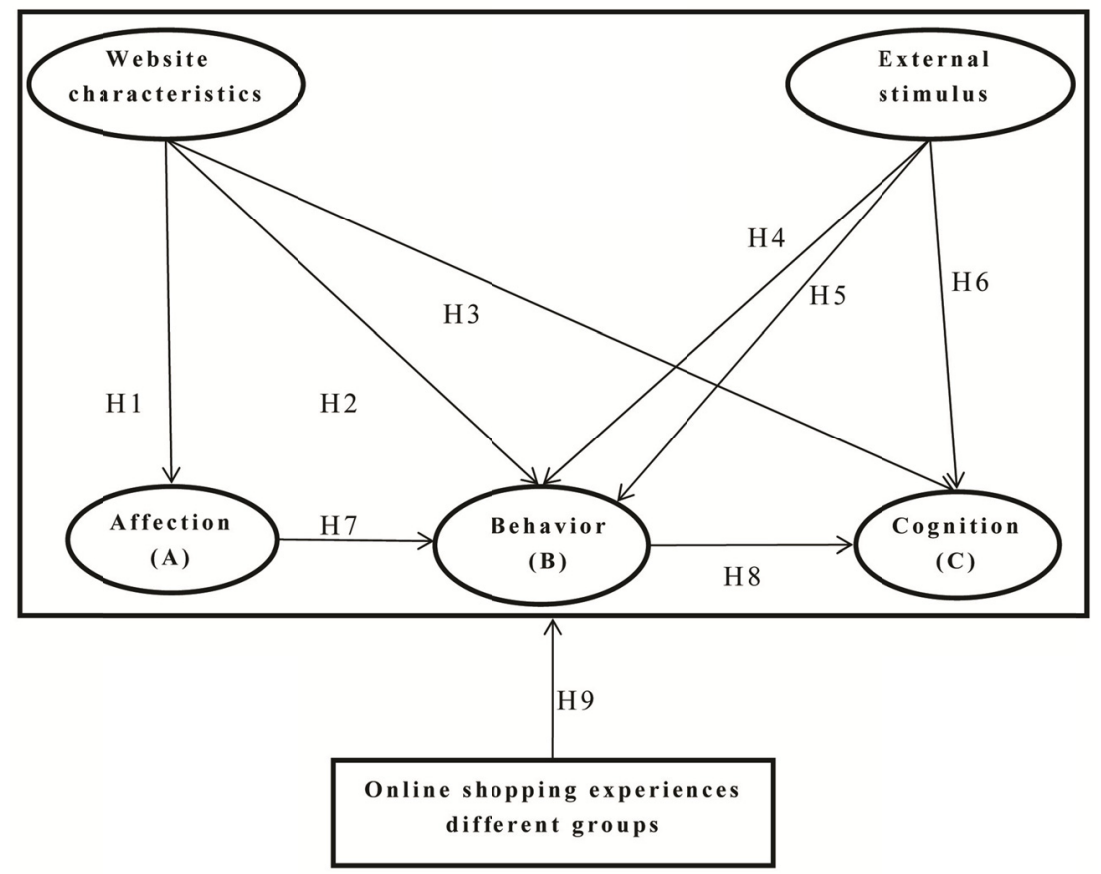

Figure 1. Research framework

\subsection{Research Method and Procedures}

This study began firstly with the design of the first draft of the questionnaire on the basis of the above theories and literature review, which was followed by a pre-test on and revision of it through interviews, thus deciding the content of the formal questionnaire. In terms of the population selection, young people that use the Internet frequently were targeted as the major groups and the ultimate respondents were those consumers who had shopped online before. It is hoped that by analyzing the opinions of the respondents, we could understand whether website characteristics and external stimuli are influential on consumers during their online shopping.

With consumers aged 15 or above in Taiwan that have shopped online as the research subjects, a convenience sampling was conducted in this study using the questionnaires distributed manually to them. 


\section{Research Results}

\subsection{Sample Structure}

With people with online shopping experiences as the research subjects, 850 questionnaires are distributed in this study through convenience sampling. Removing the 32 invalid ones, a total of 818 valid questionnaires are obtained, making the valid collection rate $96.2 \%$. The samples are then analyzed from eight perspectives. In terms of basic personal information, women account for the majority of $51.2 \%$; in terms of age, those aged between 25-34 account for the majority of $38.4 \%$, which is followed by those aged $15-24$, taking up $29.7 \%$ of the total; in terms of place of residence, those living in central Taiwan account for the majority of $49 \%$, which is followed by those living in south Taiwan, taking up $27.8 \%$ of the total; in terms of educational background, those with a college (special college) education account for the majority of $53.9 \%$, which is followed by those with a high school (vocational school) education, taking up $24 \%$ of the total; in terms of occupation, those working in the service industries account for the majority of $24.3 \%$, which is followed by students, taking up $19.6 \%$ of the total; in terms of average personal monthly or disposal income, those earning TWD 10,001 30,001 per month account for the majority of $34.7 \%$, which is followed by those earning TWD 30,000 50,001 per month, taking up $25.4 \%$ of the total; in terms of average hours spent online, those spending more than 4 hours online a day account for the majority of $35.2 \%$, which is followed by those spending 3-4 hours a day online, taking up $19.6 \%$ of the total; in terms of the average frequency of online shopping, those shopping online for one week to one month out of a year account for the majority of $46.2 \%$, which is followed by those shopping online for one to three months out of a year, taking up $20 \%$ of the total.

\subsection{Validity and Reliability Analyses on the Formal Questionnaire}

After conducting the survey using the formal questionnaire, in order to ensure the validity of the questionnaire, validity and reliability analyses are carried out on all measuring dimensions adopted in this study. Cronbach's $\alpha$, factor analysis and other methods are used for this purpose. According to what was proposed in (1978), namely value of Cronbach's $\alpha$ should be greater than 0.7 to indicate a high internal coherence, or high reliability; and the principle proposed in Kerlinger (1978) that item-to-total correlation coefficient should be greater than 0.5, the results show that all the dimensions are compliant with these standards of Cronbach's $\alpha$ value and correlation coefficient, meaning that the questionnaire used in this study has a satisfactory reliability in general (e.g., Table $1)$.

In terms of the validity of this questionnaire, factory analysis is used to test the questionnaire's convergence validity. In accordance moreover with the standards proposed in Kaiser (1958) that the eigenvalue of factors extracted should be greater than 1, that the factor loadings of the variables on all the constructs should be greater than 0.5 , and that cumulative explained variation should be greater than 0.5 , the corresponding values of all constructs are all greater than these standards, showing that the questionnaire used in this study has moreover a good convergent validity (e.g., Table 1).

In addition, composite reliability (CR) and average variance extracted (AVE) of the latent variables are used in this study to further evaluate reliability and validity. According to the principle that CR should be greater than 0.6 and AVE should be greater than 0.5 (Fornell \& Larcker, 1981), CR of the various constructs and latent variables in this study is found to be between 0.8959 and 0.9543 , all greater than 0.6 , thus indicating that the constructs of this study are satisfactorily coherent with each other internally. Given moreover that the AVE of the latent variables is found to be between 0.5774 and 0.7235 , all greater than 0.5 and hence satisfactory, showing that all the measurement items of the constructs are highly coherent (e.g., Table 1). 
Table 1. Analysis of the reliability and validity of the official questionnaire

\begin{tabular}{|c|c|c|c|c|c|c|c|c|}
\hline Factor & Mean & $\begin{array}{l}\text { Item-to-total } \\
\text { correlation } \\
\text { coefficient }\end{array}$ & $\begin{array}{l}\text { Factor } \\
\text { loading }\end{array}$ & Eigenvalue & $\begin{array}{l}\text { cumulative } \\
\text { explained } \\
\text { variation } \%\end{array}$ & $\begin{array}{l}\text { Cronbach } \alpha \\
\text { value }\end{array}$ & $\begin{array}{l}\text { Component } \\
\text { reliability } \\
(\mathrm{CR})\end{array}$ & $\begin{array}{l}\text { Average } \\
\text { variance } \\
\text { extracted } \\
\text { (AVE) } \\
\end{array}$ \\
\hline \multicolumn{9}{|l|}{ Website characteristics } \\
\hline $\begin{array}{l}\text { The online shopping website is } \\
\text { designed with a good interface. }\end{array}$ & 5.4600 & .801 & .847 & 6.927 & 57.725 & .932 & 0.9418 & 0.5774 \\
\hline $\begin{array}{l}\text { The online shopping website } \\
\text { allows for a diversified means of } \\
\text { payment. }\end{array}$ & 5.2700 & .808 & .841 & & & & & \\
\hline $\begin{array}{l}\text { The online shopping website sets } \\
\text { one's mind at rest when } \\
\text { providing personal data. }\end{array}$ & 5.2800 & .775 & .829 & & & & & \\
\hline $\begin{array}{l}\text { The online shopping website is } \\
\text { updated on a real-time or regular } \\
\text { basis. }\end{array}$ & 5.3400 & .761 & .816 & & & & & \\
\hline $\begin{array}{l}\text { The online shopping website } \\
\text { comes with safe transaction } \\
\text { mechanisms. }\end{array}$ & 5.6050 & .775 & .810 & & & & & \\
\hline $\begin{array}{l}\text { The online shopping website } \\
\text { makes it easy to find the } \\
\text { information one needs. }\end{array}$ & 5.0600 & .759 & .800 & & & & & \\
\hline $\begin{array}{l}\text { The online shopping website } \\
\text { makes it easy to find the } \\
\text { information one needs. }\end{array}$ & 5.1850 & .734 & .793 & & & & & \\
\hline $\begin{array}{l}\text { The online shopping website } \\
\text { provides a rich amount of } \\
\text { information in details. }\end{array}$ & 4.8650 & .666 & .734 & & & & & \\
\hline $\begin{array}{l}\text { The online shopping website is } \\
\text { designed with satisfactory } \\
\text { operational interfaces. }\end{array}$ & 4.8200 & .614 & .730 & & & & & \\
\hline $\begin{array}{l}\text { It is safe to have transactions on } \\
\text { the online shopping website. }\end{array}$ & 5.6600 & .558 & .669 & & & & & \\
\hline $\begin{array}{l}\text { The online shopping website will } \\
\text { not cause any data leakage. }\end{array}$ & 5.8550 & .614 & .619 & & & & & \\
\hline $\begin{array}{l}\text { The online shopping website is } \\
\text { designed with a good interface. }\end{array}$ & 5.2850 & .696 & .569 & & & & & \\
\hline \multicolumn{9}{|l|}{ External stimulus } \\
\hline $\begin{array}{l}\text { The online shopping website } \\
\text { makes sure that consumers could } \\
\text { buy intact products on it. }\end{array}$ & 5.300 & .720 & .872 & 6.052 & 67.245 & .935 & 0.9543 & 0.6363 \\
\hline $\begin{array}{l}\text { The online shopping website } \\
\text { makes sure that the products } \\
\text { displayed on it are the cheapest. }\end{array}$ & 5.2600 & .786 & .864 & & & & & \\
\hline $\begin{array}{l}\text { The online shopping website } \\
\text { makes sure that the products } \\
\text { displayed on it are } \\
\text { quality-guaranteed. }\end{array}$ & 5.4600 & .696 & .836 & & & & & \\
\hline $\begin{array}{l}\text { The online shopping website } \\
\text { launches new products on a } \\
\text { frequent basis. }\end{array}$ & 5.2800 & .750 & .826 & & & & & \\
\hline $\begin{array}{l}\text { The online shopping website } \\
\text { makes sure that the products } \\
\text { displayed on it are satisfactory } \\
\text { and of good quality. }\end{array}$ & 5.2900 & .766 & .821 & & & & & \\
\hline $\begin{array}{l}\text { The online shopping website } \\
\text { makes sure that consumers could } \\
\text { receive promotional information } \\
\text { in real time. }\end{array}$ & 5.3400 & .805 & .811 & & & & & \\
\hline
\end{tabular}


The prices on the online shopping website are set in a reasonable manner.

The products displayed on the online shopping website allows for greater bargaining space.

The online shopping website is designed with a satisfactory return/exchange mechanism.

The online shopping website is designed with a satisfactory interaction mechanism with customers.

The online shopping website needs immediately.

The online shopping website makes sure that consumers could buy discount products on it. could respond to customers'

$5.6050 \quad .670 \quad .804$

$5.0650 \quad .780$

$5.2350 \quad .769$

$5.1550 \quad .538$

.686

$\begin{array}{lll}5.3050 \quad .617 & .661\end{array}$

$\begin{array}{lll}5.6600 \quad .644 & .538\end{array}$

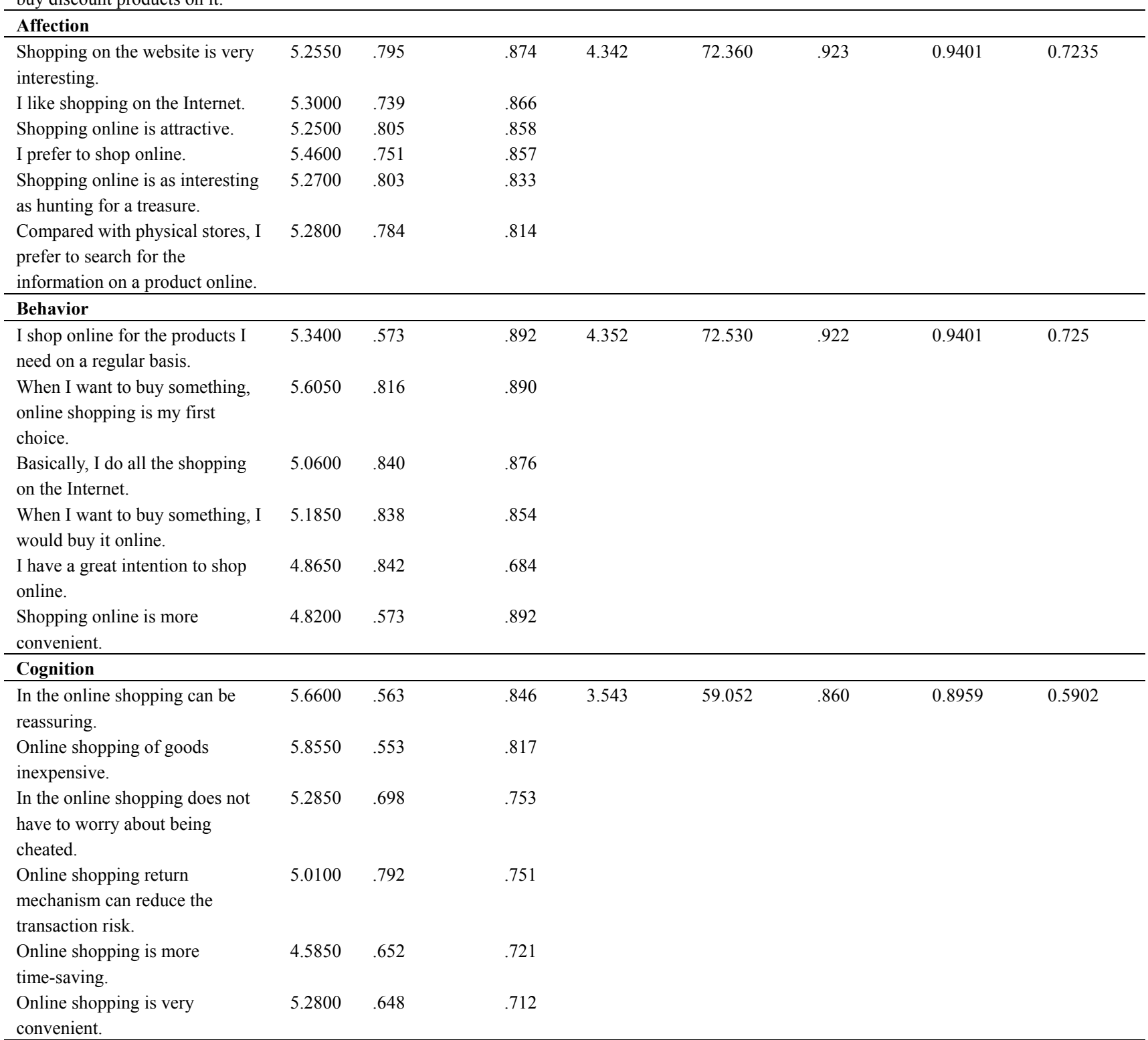




\subsection{Confirmatory Factor Analysis}

In order to confirm the efficiency of the various measuring dimensions proposed in this study, a confirmatory factory analysis (CFA) is conducted via the software AMOS on the measuring models of such five dimensions as website characteristics, external stimuli, emotion, behavior and cognition. According to what was proposed in Carmines \& MacIver (1981), the indicator of fit for the model should meet the ideal standards that the degree of freedom in the chi-square test should be $\leqq 3$, RMR (Root mean square residual) and (Root mean square error of approximation) be smaller than 0.05, and GFI (Goodness of fit index), AGFI (Adjusted goodness of fit index), NFI (Normed fit index) and CFI (Comparative fit index) be greater than 0.9. In (Bagozzi \& Yi, 1988; Joreskog \& Sorbom, 1989) and Sharma (1996), it was suggested that when GFI was greater than 0.8, the model could be said to have a satisfactory fit. Segars \& Grover (1993) also suggested that the model should be considered as acceptable if it complied with the principle that AGFI is greater than AGFI. According to the results of this study, among all the indicators of fit for the measurement model as a whole, $\chi^{2} / \mathrm{df}$ value is 1450.132 , GFI value is 0.700 , AGFI value is 0.868 , NFI value is 0.897 , RFI value is 0.873 , CFI value is 0.943 , RMSEA value is 0.042 , and RMR value is 0.050 , from which it could be concluded that all the indicators of fit for the measurement model proposed in this study are within the acceptable interval. This means that the measurement model in this study has a good fit, showing that these measurements indicators have both construct validity and measurement efficiency.

\subsection{Comparative Analysis of the Competing Model between Multiple Groups}

Given that 818 valid questionnaires are collected in this study, based on the frequency of online shopping, namely using the average time of online shopping as the basis of categorization, those who shop online once in one week to three months as the high-frequency online shopping group, involving a total of 641 questionnaires; those who shop online once in three months to one year's time as the low-frequency online shopping group, involving a total of 177 questionnaires.

Using AMOS, the software, a comparative analysis is conducted on the high-frequency and low-frequency groups to see whether the differences in online shopping experience are significantly influential on the relationship between different constructs. According to the analysis of the fit of the competing model, $\chi 2 / \mathrm{df}$ value is 3.441 , RMR value is 0.035 , GFI value is 0.866 , AGFI value is 0.846 , NFI value is 0.760 , RFI value is 0.737 , CFI value is 0.816 and RMSEA value is 0.039 , all satisfying the standards of a satisfactory model, which means that the competing model proposed in this study has a good fit, hence an acceptable model. According to the analysis on the competing model (e.g., Table 2):

(1). In terms of the degree of influences imposed by website characteristics on consumers' affection (H1), high-frequency group is significantly different from low-frequency group ( $\mathrm{t}=3.494)$. Although these influences on two groups are both positive, the coefficient of the high-frequency online shopping group is greater, showing that a higher frequency of online shopping on the part of consumers will indeed increase their emotion toward online shopping.

(2). Along the path showing the influence of website characteristics on consumers' behavior (H2), significant differences are seen between the two groups in terms of the degree of influence $(t=2.425)$. Comparing the influence coefficient, it is found that the influence between the two variables are both positive for the two groups, meaning that website characteristics are significantly positively influence on consumers' behavior, the low-frequency online shopping group in particular. This shows that consumers from the low-frequency online shopping group will also be affected by the satisfactory website characteristics of an online shopping website as to develop a greater purchase intention online.

(3). Along the path showing the influence of website characteristics on consumers' cognition (H3), no significant differences are seen between the two groups in terms of the degree of influence $(t=-1.463)$. In terms of the influence coefficient, however, this influence is positive for people from the high-frequency online shopping group, showing that consumers from the high-frequency online shopping group will more be affected by the satisfactory website characteristics of an online shopping website as to develop better cognition toward online shopping.

(4). In terms of the influence of external stimuli on consumers' affection at the time of online shopping (H4), no significant differences are seen between the two groups in terms of the degree of influence $(t=-0.984)$. In terms of the influence coefficient, this influence are positive for both groups with different online shopping experience, meaning that consumers from both groups will be influenced emotionally by the external stimuli they are exposed to during online shopping. 
(5). In terms of the influence of external stimuli on consumers' behavior at the time of online shopping (H5), no significant differences are seen between the two groups in terms of the degree of influence $(t=0.28)$. In terms of the influence coefficient, this influence are positive for both groups with different online shopping experience, meaning that behaviors of consumers from both groups will be influenced by the external stimuli they are exposed to during online shopping.

(6). In terms of the influence of external stimuli on consumers' cognition at the time of online shopping (H6), no significant differences are seen between the two groups in terms of the degree of influence ( $t=-1.291)$. In terms of the influence coefficient, this influence are positive for both groups with different online shopping experience, meaning that consumers from both groups will be influenced cognitively by the external stimuli they are exposed to during online shopping.

(7). In terms of the influence of consumers' affection on consumers' behavior at the time of online shopping (H7), significant differences are seen between the two groups in terms of the degree of influence $(t=3.79)$. In terms of the influence coefficient, this influence are highly significantly positive for both groups, and especially so for the high-frequency online shopping group.

(8). In terms of the influence of consumers' behavior on consumers' cognition at the time of online shopping (H8), no significant differences are seen between the two groups in terms of the degree of influence $(\mathrm{t}=-1.64)$. In terms of the influence coefficient, this influence are significantly positive for both groups with different online shopping experience, meaning that the more consumers actually shop online, the more positive the cognition they have toward online shopping will be.

Given the above, it is known that the two groups with different online shopping experiences are significantly different in terms of the degree of influence along the paths between all the constructs. This means that differences in the frequency of online shopping will be reflected as significant differences in the degree of influence along some relational paths, which supports $\mathrm{H} 9$ partly. It could thus be concluded that differences in the frequency of online shopping will actually cause differences in the relational structure, which is an important finding of this study.

Table 2. Comparative analysis of the multi-group competing model

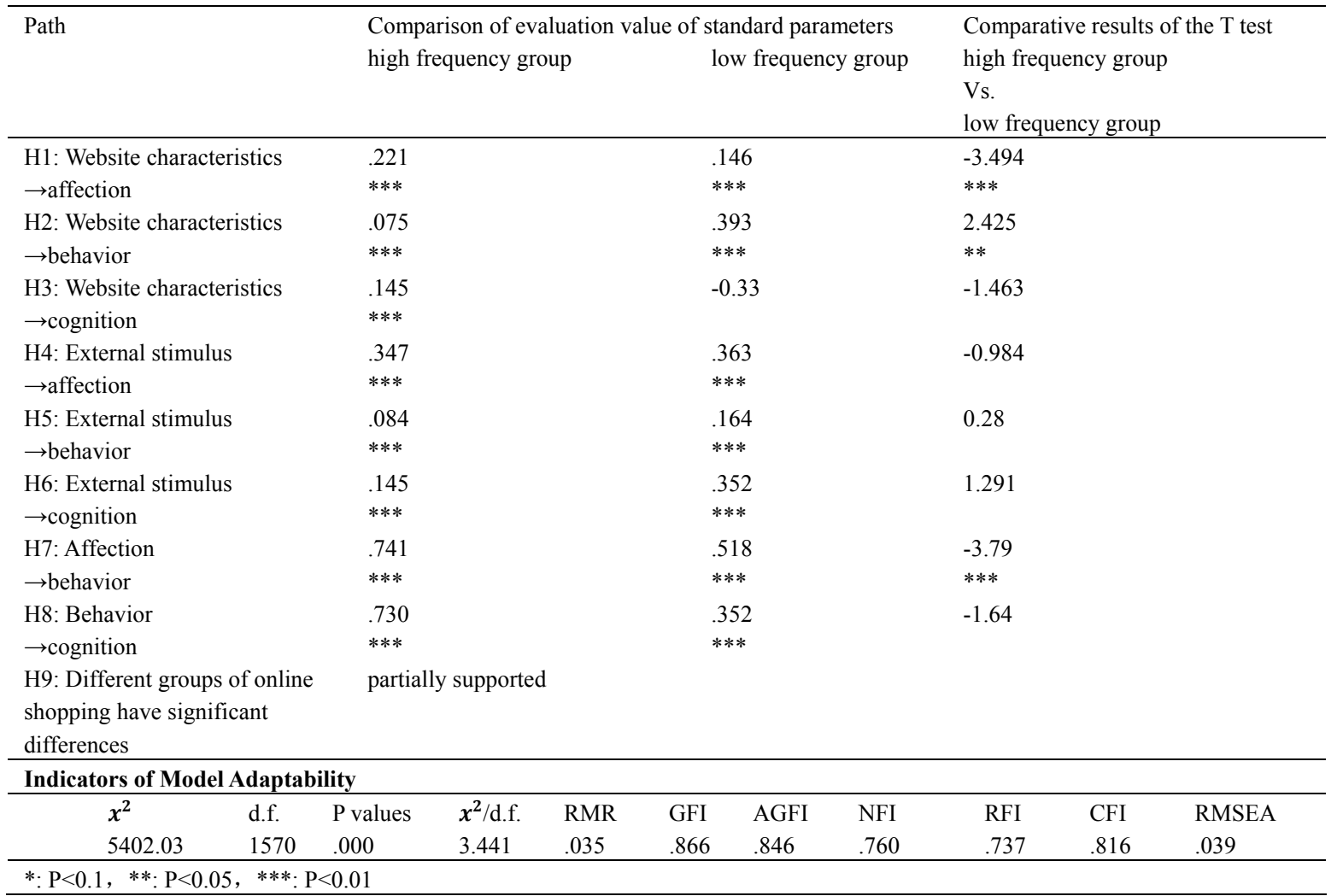




\section{Conclusion and Suggestions}

\subsection{Conclusion}

With people that have shopped online before as the research subjects and with website characteristics and external stimuli as the two independent variables, this study is set out to analyze the influences of the independent variables on "affection", "cognition" and "behavior", namely the three components of consumers' attitude toward online shopping. A relationship model is moreover established to compare the differences between groups with different online shopping experiences. Given the importance of its conceptual framework and research tool to the academic field and industries, this study could therefore be said to be significant both academically and practically. The research findings are hereby presented as follows:

(1). For consumers of the "high-frequency online shopping group", their emotion is most significantly influenced by website characteristics. This means that people from the high-frequency online shopping group will be more affected by the satisfactory website characteristics of an online shopping website as to develop a positive emotion toward online shopping.

(2). For consumers of the "low-frequency online shopping group", characteristics of the online shopping website are found to be mostly influential on their behaviors. This means that people from this group will develop the intention to shop online, and then actually shop online, if the online shopping website is rich in content and good in design.

(3). For consumers of the "high-frequency online shopping group", the external stimuli they are exposed to during the time of online shopping are more significantly influential on their emotion, meaning that even with consumers shopping online frequently, their emotion toward online shopping will be even more positive when external stimuli are present.

(4). For both groups with different online shopping experiences, a high significant influence relationship is found between consumers' affection and behavior, meaning that once a consumer develops a positive emotion toward online shopping, it will be transformed effectively into the actual behavior of shopping online.

(5). For both groups with different online shopping experiences, a high significant influence relationship is found between consumers' emotion and cognition, meaning that once a consumer actually begins to shop online, it will be lead effectively to their positive cognition of online shopping.

\subsection{Managerial Implications}

Based on the differences and similarities between groups with different online shopping experiences found in the linear structural model comparison conducted in this study, the following managerial implications and suggestions are arrived at:

People from the high-frequency online shopping group place greater importance on the website characteristics of an online shopping platform. It is therefore advisable for business owners to improve the quality of their system at the time of building the online shopping website by giving the website with richer content and better web page design. Meanwhile, it is also necessary for them to enhance the security of the website. They could for example encrypt the website, protect consumers' personal information, design firewalls, etc. Thus increasing the security and privacy of the website, they could hope to dispel the doubts harbored by consumers. Only in this way could they deepen the emotion toward online shopping among people from the high-frequency online shopping group, thus causing them to entertain the intention to shop online and actually buy things online.

People from the low-frequency online shopping group are exposed to online shopping on a less frequent basis. For them, significant influences are seen on the path of external stimuli. That is why operators of online shopping platforms should provide discount prices, along with satisfactory service quality and promotional plans (for example, responding to the customers in the shortest time possible via one-to-one online QA and guiding them toward online shopping in a gradual manner), to increase consumers' intention to use the online shopping platform and buy things on it.

Since significant influences are seen among consumers from the two groups with different online shopping experiences when it comes to affection, behavior and cognition, it means that different strategies should be made for different groups. It is also advisable to establish such mobile marketing systems like online dynamic pricing so that consumers could be exposed to the marketing activities. Thus boosting consumers' emotion toward online shopping effectively, it might be possible to increase their purchase intention and behavior in a positive manner. Lastly, positive influences on consumers' cognition are found to contribute to their repurchase rate on an online shopping website. 


\subsection{Research Limitations and Future Studies Suggestions}

In this study, only consumers aged 15 or above and have moreover shopped online before are used as the research subjects. However, as the Internet is never boundless, consumers in Taiwan are also given access to shopping platforms of other countries, on which they could place orders to buy things easily from other countries via methods of online payment. This means that online shopping is not limited to Taiwan geographically, and the shopping platforms and means of online shopping of these other countries might be different from their counterparts in Taiwan. It is therefore suggested that future studies should extend the scope of research to test the applicability of the ideas and models proposed in this study.

\section{References}

Ajzen, I. (1985). From intention to actions: a theory of planned behavior. In J. Kuhl \& J. Bechmann (Eds.), Action-control: from Cognition to Behavior. https://doi.org/10.1007/978-3-642-69746-3_2

Ajzen, I., \& Fishbein, M. (1980). Understanding Attitude and Predicting Social Behavior. New Jersey: Prentice hall lnc.

Alba, J., Lynch, J., Barton, W., Janiszewski, C., Lutz, R., Sawyer, A., \& Wood, S. (1997). Interactive home shopping: consumer, retailer, and manufacturer incentives to participate in electronic market places. Journal of Marketing, 61(3), 38-53. https://doi.org/10.2307/1251788

Antil, J. (1988). New product or service of adoption: when does it happen. Journal of Consumer Marketing, 5-16. https://doi.org/10.1108/eb008221

Bagozzi, R., Gopinath, M., \& Nyer, P. (1999). The role of emotions in marketing. Journal of the Academy of Marketing Science, 27(2), 184-206. https://doi.org/10.1177/0092070399272005

Beatty, S., \& Ferrell, M. (1998). Impulse buying: modeling its precursors. Journal of Retailing, 74(2), 169-191.

Bei, L. T., \& Chiao, Y. C. (2001). An integrated model for the effects of perceived product, perceived service quality, and perceived price fairness on consumer satisfaction and loyalty. Journal of Consumer Satisfaction, Dissatisfaction and Complaining Behavior, 14, 125-140.

Belk, R. W. (1975). Situational variables and consumer behavior. Journal of Consumer Research, 1(2), 157-164. https://doi.org/10.1086/208627

Breckler, S. J. (1984). Empirical validation of affect, behavior, and cognition as destine components of attitude. Journal of Personality and Social Psychology, May, 1191-1205. https://doi.org/10.1037/0022-3514.47.6.1191

Bruicker, F. S. D. (1979). An appraisal of low involvement consumer information processing. In J. Maloney \& B. Silverman (Eds.), Attitude research plays for high stakes, Chicago (pp. 93-100). American Marketing Association.

Cairncross, F. (1997). How the Communications Revolution will Change Our Live. Boston: Harvard Business school press.

Cheng, K. F. (2013). Consumer Behavior: Life and Marketing (2nd ed.). Taipei: Future Career Publishing corporation.

Childers, T. L. (1986). Assessment of the psychometric properties of an opinion leadership scale. Journal of Marketing Research, 23, 184-188. https://doi.org/10.2307/3151666

Cohen, J. B., \& Charles, S. A. (1991). Affect and consumer behavior. In T. S. Robertson \& H. H. Kassarjian (Eds.), Handbook of Consumer Behavior (pp. 188-240). Englewood Cliffs, NJ: prentice hall.

Covaleski, J. (1997). Panel: internet marketing may reduce prices. Best's Review P/C, 71-72.

Daniel, J. (2000). Developing usable web site-review and model. Internet Research: Electronic Networking Applications and Policy, 10(4), 295-307. https://doi.org/10.1108/10662240010342577

Dayal, S., Landesberg, H., \& Zeisser, M. (1999). How to build trust online. Marketing Management, 8(3), 64-69.

Doolin, B., Dillon, S., Thompson, F., \& Corner, J. L. (2005). Perceived risk, the internet shopping experience and online purchasing behavior: a New Zealand perspective. Journal of Global Information Management, 13(2), 66-88. https://doi.org/10.4018/jgim.2005040104

Gillett, P. L. (1976). In-home shoppers: an overview. Journal of Marketing, 40, 81-88. https://doi.org/10.2307/1251072 
Hanna, N., \& Wozniak, R. (2001). Consumer Behavior (1st ed.). South-west college publishing. Upper Saddle River, New Jersey: Prentice-hall, Inc.

Hoffman, D. L., \& Novak, T. P. (1995). Marketing in hypermedia computer mediated environments; conceptual foundations. Journal of Marketing, 60, 50-68. https://doi.org/10.2307/1251841

Holak, S. L. (1988). Determinants of innovative durables adoption an mpirical study with implications for early product screening. Journal of Product Innovation Management, 5(1), 59-73. https://doi.org/10.1016/0737-6782(88)90032-X

Huizingh, E. K. R. E. (2000). The content and design of web sites an empirical study. Information \& Management, 37(3), 123-134. https://doi.org/10.1016/S0378-7206(99)00044-0

Janda, S., Trocchia, P. J., \& Gwinner, K. P. (2002). Consumer perceptions of internet retail service quality. International Journal of Service Industry Management, 13(5), 412-431. https://doi.org/10.1108/09564230210447913

Kathy, N. S., \& Mohamed, K. (2012). System design effects on online impulse buying. Internet Research, 22(4), 396-425. https://doi.org/10.1108/10662241211250962

Keeler, L. L. (1995). How to extend your e-mail reach. Supervisory Management, 40(8), 8-13.

Kim, S., \& Stoel, L. (2004). Dimensional hierarchy of retail website quality. Information \& Management, 41(5), 619-633. https://doi.org/10.1016/j.im.2003.07.002

Kotler, P. (2003). Marketing Management (11th ed.). New Jersey: Prentice-hall Inc.

Kwak, H., Fox, R. J., \& Zinkhan, G. M. (2002). What products can be successfully promoted and sold via the Internet. Journal of Advertising Research, 42(1), 23-38. https://doi.org/10.2501/JAR-42-1-23-38

Laia, C. Y., Lia, Y. M., \& Lin, L. F. (2017). A social referral appraising mechanism for the e-marketplace. Information \& Management, 54, 269-280. http://dx.doi.org/10.1016/j.im.2016.07.001

Lewis, T. G. (1997). The friction-free economy-marketing strategies for a wired world. North Carolina: Harper Collins.

Liebermann, Y., \& Stashevsky, S. (2002). Perceived risks as barriers to internet and e-commerce usage. Qualitative Market Research: An International Journal, 5(4), 291-300. https://doi.org/10.1108/13522750210443245

Lin, J. H. (2002). Marketing. Taipei: Hwa Tai publishing.

Lutz, R. J. (1991). The role of attitude theory in marketing. In H. H. Kassarjian \& T. Rrobertson (Eds.), Perspectives in consumer behavior (4th ed.). Glen View, IL: Scott, Foresman and Company.

Mallapragada, G., Chandukala, S. R., \& Qing, L. (2016). Exploring the effects of "What" (Product) and "Where" (Website) characteristics on online shopping behavior. Journal of Marketing, 80(2), 21-38. https://doi.org/10.1509/jm.15.0138

Manganari, E. E., Siomkos, G. J., \& Vrechopoulos, A. P. (2009). Store atmosphere in web retailing. European Journal of Marketing, 43(9/10), 1140-1153.

Market Intelligence \& Consulting Institute. (2012). Online shopping survey on netizens in Taiwan. Market Intelligence \& Consulting Institute.

Martin, L., \& Charles, J. (1999). Net Future. New York: Mcgraw-hill company.

McCorkle, D. E. (1990). The role of perceived risk in mail order catalog shopping. Journal of Direct Marketing, 4, 26-35. https://doi.org/10.1002/dir.4000040406

Mehta, R., \& Sivadas, E. (1995). Direct marketing on the internet: an empirical assessment of consumer attitudes. Journal of Direct Marketing, 9, 21-32. https://doi.org/10.1002/dir.4000090305

Modahl, M. (2000). Now or Never. Cambridge: Forrester Research.

Park, J. W. (2007). Passenger perceptions of service quality: Korean and Australian case studies. Journal of Air Transport Management, 13(4), 238-242. https://doi.org/10.1016/j.jairtraman.2007.04.002

Peter, J. P., \& Olson, J. (2001). Consumer Behavior and Marketing Strategy. New York, NY: Mcgraw hill.

Philip, K., \& Gary, A. (1997). Marketing: An Introduction (4th ed., p. 251).

Prashar, S., Sai, V. T., \& Parsad, C. V. (2017). Effects of online shopping values and Website cues on purchase 
behaviour: A study using S-O-R framework. The Journal for Decision Makers, 42(1), 1-18. https://doi.org/10.1177/0256090916686681

Puri, R. (1996). Measuring and modifying consumer impulsiveness: a cost-benefit accessibility framework. Journal of Consumer Psychology, 5(2), 87-113. https://doi.org/10.1207/s15327663jcp0502_01

Quelch, J. A., \& Klein, L. R. (1996). The internet and international marketing. Sloan Management Review, 37(3), 60-75.

Ranganathan, C., \& Ganapathy, S. (2002). Key dimensions of business-to-consumer web sites. Information \& Management, 39(6), 457-465. https://doi.org/10.1016/S0378-7206(01)00112-4

Ray, A. (1973). Marketing communication and the hierarchy of effects. New, Model for Mass Communication Research, 2, 147-176.

Richmond, A. (1996). Enticing online shoppers to buy: a human behavior study. Computer Network and Isdn Systems, 28, 1469-1480. https://doi.org/10.1016/0169-7552(96)00058-X

Rogers, E. M. (1962). Diffusion of Innovation. New York: Free Press.

Salisbury, W. D., Pearson, R. A., Pearson, A. W., \& Miller, D. W. (2001). Perceived security and world wide web purchase intention. Industrial Management Data Systems, 101(3/4), 165-176. https://doi.org/10.1108/02635570110390071

Sawyer, A. G. (1984). Psychological perspective on consumer respond to sale promotion, research on sale promotion: collected paper. Market Science Institute, 1, 21.

Solomon, M. R. (2002). Consumer Behavior Buying, Having and Being. NJ: Prentice hall.

Solomon, M. R. (2011). Consumer Behavior (9th ed.). Upper Saddle River, NJ: Pearson Education.

Turban, E., King, D., Lee, J., Warkentin, M., \& Chung, H. M. (2002). Electronic Commerce: A Managerial Perspective. Upper Saddle River, NJ: Prentice hall.

Van den Poel, D., \& Leunis, J. (1999). Consumer acceptance of the internet as a channel of distribution. Journal of Business Research, 45, 249-256. https://doi.org/10.1016/S0148-2963(97)00236-1

Verhagen, T., \& Van Dolen, W. (2011). The influence of online store beliefs on consumer online impulse buying: a model and empirical application. Information Management, 48(7), 320-327. https://doi.org/10.1016/j.im.2011.08.001

Wirtz, J., \& Bateson, J. E. G. (1999). Consumer satisfaction with service: integrating the environment perspective in service marketing into the Traditional Disconfirmation Paradigm. Journal of Business Research, 44, 55-66. https://doi.org/10.1016/S0148-2963(97)00178-1

Wirtz, J., \& John, E. G. (1995). An experimental investigation of halo effects in satisfaction measures of service attributes. International Journal of Service Industry Management, 6, 84-102. https://doi.org/10.1108/09564239510091358

Wu, S. I., \& Tsai, H. T. (2016). Exploring the effects of Website characteristics and external stimulus on consumers' online shopping by ABC attitude model. The 2016 cross-strait technology, humanity education and Academy-Industry cooperation conference. The 2016 conference on sustainable operation and development.

Yahoo financial news. (2015). Report on internet use and broadband adoption in Taiwan. Retrieved from Taiwan Network Information Center.

\section{Copyrights}

Copyright for this article is retained by the author, with first publication rights granted to the journal.

This is an open-access article distributed under the terms and conditions of the Creative Commons Attribution license (http://creativecommons.org/licenses/by/4.0/). 